\title{
First RECORD OF OVERLAP BETWEEN TWO SPECIES OF PINGUiCULA IN THE ANDEAN PATAGONIAN FOREST
}

\author{
Federico Ezequiel Parrilli • and • María Victoria Coppini • Carnívoras Argentina Project • www. \\ carnivorasargentina.com $•$ carnivorasargentina@gmail.com
}

Keywords: Carnivorous plants, overlap, Pinguicula australandina, Pinguicula antarctica.

\begin{abstract}
In Argentina there are two species of carnivorous plants of the genus Pinguicula, P. antarctica, and $P$. australandina. These species, also present in Chile, have a distribution in Argentina limited to the Andean Patagonian Forest ecoregion, which ranges from southern Neuquén to Tierra del Fuego and Isla de los Estados. To date, no cases of overlap between these two Pinguicula species have been reported. Knowing the distribution of species is a key component to understanding their ecology and conservation. The study of the carnivorous plants of Argentina contributes to increase the knowledge of the native flora.
\end{abstract}

\section{Introduction}

The Pinguicula species of Argentina are perennial herbs that grow as rosettes attached to the ground that rarely exceed $3.5 \mathrm{~cm}$ in diameter. The upper side of the leaves are covered with glands that produce a mucilaginous secretion. Small insects get stuck in the mucilage and are degraded by enzymes secreted by the referred glands. The absorbed nutrients are important sources of nitrogen for these plants (Dawson 1973). In autumn-winter they spend several months under the snow with the same type of leaves, being homophilic species, unlike others in the genus. In summer they develop one or more inflorescences consisting of a single flower through which they reproduce sexually. At first glance the two species appear similar, but if different characters of the inflorescence are punctually compared, the morphological distinction is achieved. These two Pinguicula grow in the Andean Patagonian Forest ("Bosque Andino Patagónico") ecoregion, but in very different environments. The habitat of $P$. antarctica corresponds to the peat bogs of the Patagonian rainforest (temperate rainforest) with reported sightings in Chubut, Santa Cruz, Tierra del Fuego, and Isla de los Estados (Dawson 1973). The plants occur from sea level to elevations of approximately $1000 \mathrm{~m}$ above sea level. The associated floristic set is Subantarctic (Lampard et al. 2016).

Pinguicula australandina has been determined to occur at elevations of 1400 to $2300 \mathrm{~m}$ above sea level, mainly in alpine pastures between $36^{\circ}$ and $41^{\circ}$ South latitude both for Argentina and Chile, in the former the reported sightings place populations in Neuquén and Río Negro (Lampard et al. 2016). A particularly interesting population of $P$. australandina has been sighted in a specific location in Puerto Blest (Río Negro) (Figs. $1 \&$ 2), a habitat similar to the description of the ecosystem preferred by $P$. antarctica, growing on sphagnum peat moss and close to $790 \mathrm{~m}$ above sea level (Brion et al. 1988).

\section{Methodology}

In January 2020, within the framework of the "Carnívoras Argentina" project, an investigation was carried out in the Nahuel Huapi National Park in order to compare distinct populations of $P$. 


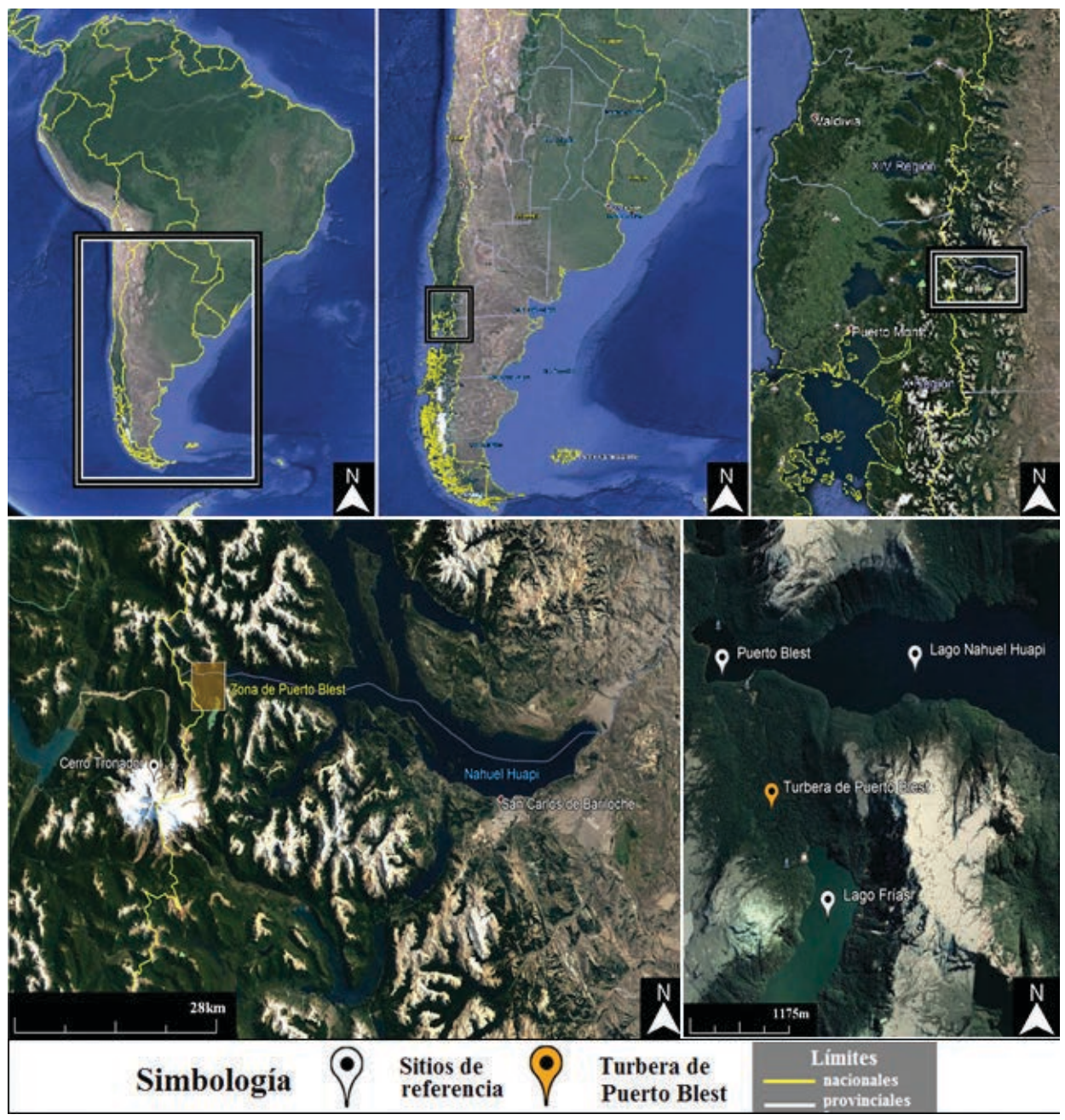

Figure 1: Location of the Puerto Blest peat bog. Satellite images taken from Google Earth. Image date according to satellite data: 10/17/2019.

australandina that exhibited morphological differences in their native habitat and determine if these differences prevailed in ex-situ cultivation (under the same growing conditions). Three previously known locations were surveyed, two of which were located in hills near the City of San Carlos de Bariloche over $1600 \mathrm{~m}$ above sea level, in high Andean pastures. The other location corresponds to the peat bog present in the Puerto Blest area. In this publication we will refer exclusively to the findings at this location. The survey method was in-situ photography, making measurements of the plants and recording the captures of invertebrates with macro photos. At the same time, with the permission of the National Parks Administration (Research Authorization - DRPN - No. 1676), live material was collected. With the collected material, two herbarium specimens were prepared.

With the photographic material generated in-situ and the collection of specimens, we proceed to review the specific bibliography with botanical description of the Pinguicula known in Argentina 


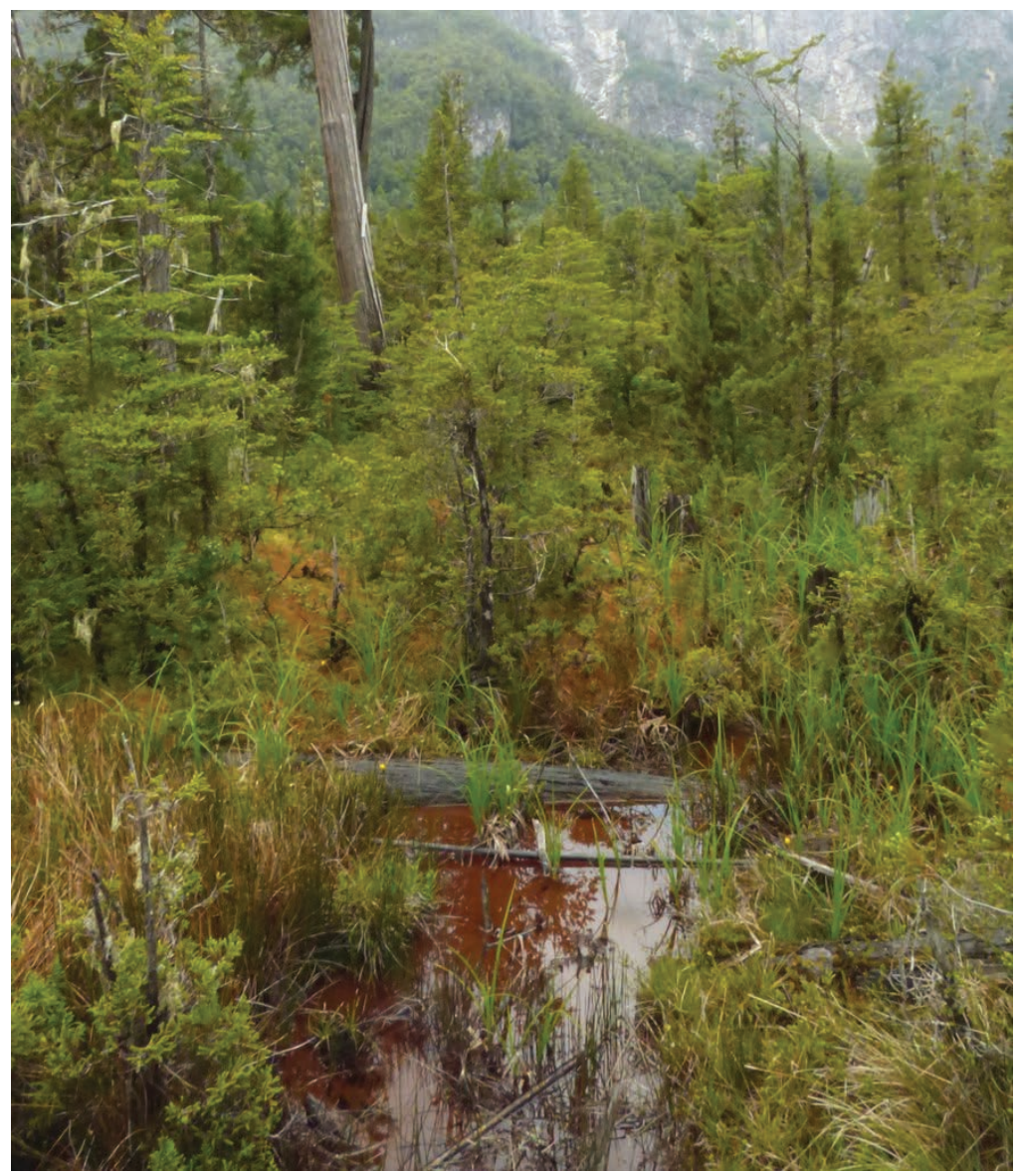

Figure 2: Puerto Blest peat bog at 790 m above sea level. Photo taken 01/07/2020.

using the most recent works on the genus, viz. Pinguicula of Latin America, Vol. 2 (Lampard et al. 2016) and the review Revision of Pinguicula (Lentibulariaceae) in Chile and Argentina (Gluch 2017a,b).

In Puerto Blest, the meteorological, soil, and consequently ecosystem characteristics differ greatly from other sectors of the Nahuel Huapi National Park, giving rise to the Valdivian Forest.

\section{Results}

The presence of $P$. australandina in Puerto Blest is at least a strange fact, considering the floristic composition and the environment where the other known populations grow in the Cerros de Río Negro in the Nahuel Huapi National Park (Roccia 2018). Despite these environmental differences, the P. australandina population from Puerto Blest did not present great differences with the other populations observed (beyond those differences in color, typical of the varying light conditions) (Fig. 3). However, it was noted that the $P$. australandina population in Puerto Blest was more advanced in terms of fruit and seed development, possibly due to being approximately $790 \mathrm{~m}$ above sea level, 

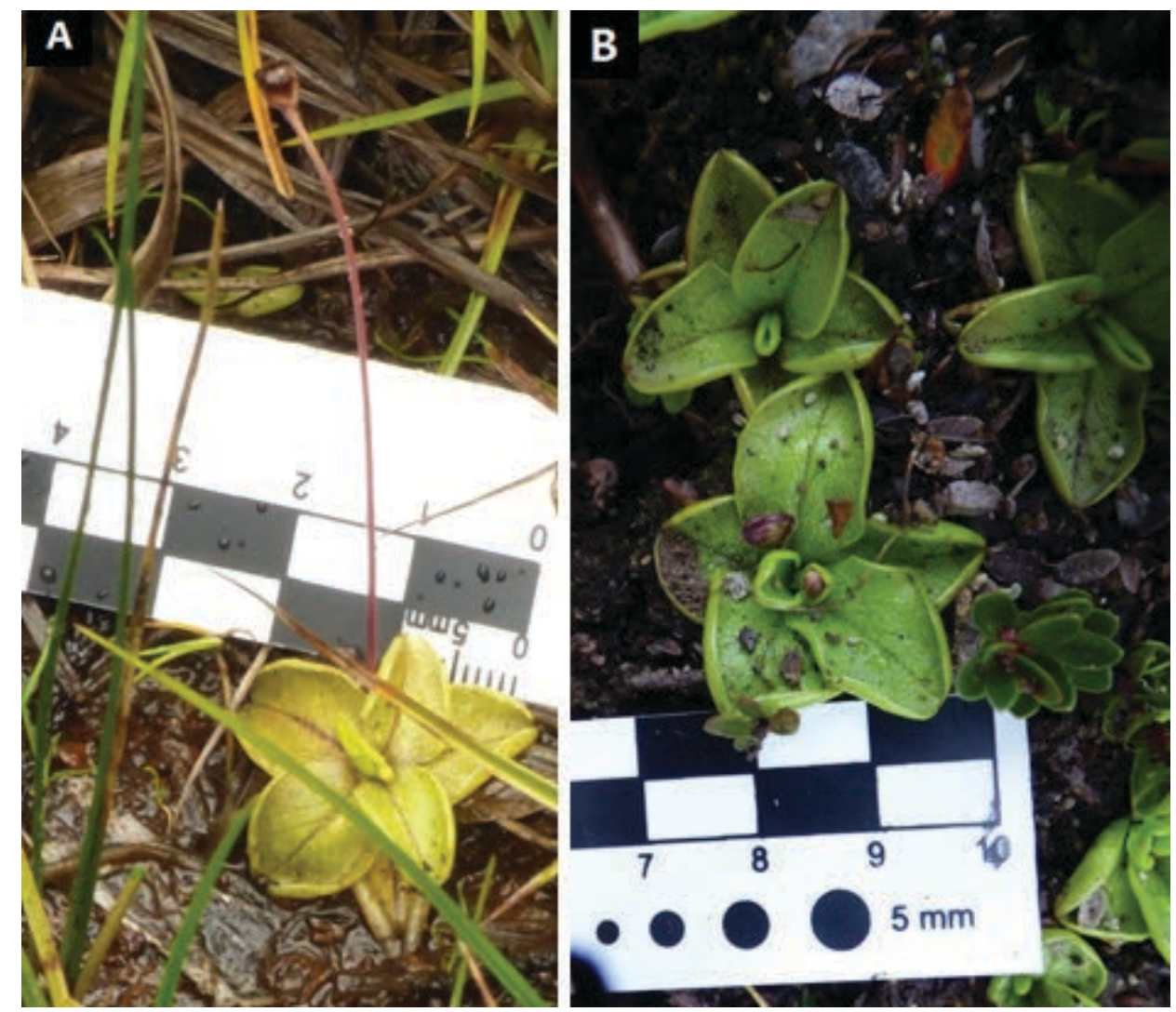

Figure 3: (A) Pinguicula australandina in Puerto Blest. Photo taken 01/07/2020. (B) Same species in a meltwater stream at $1600 \mathrm{~m}$ above sea level on a hill near San Carlos de Bariloche. Photo taken 01/05/2020.

while the populations that were above $1600 \mathrm{~m}$ above sea level were in a less developed flowering stage at the same time of the year (personal observations making comparisons in the flowering stages in an altitude gradient for the same hill).

In the survey and detailed observation in different sectors of the peat bog, where access was only possible thanks to the explicit permission of the Administration of National Parks within the framework of the proposed investigation (DRPN - N 1676), Pinguicula with very different morphology were found, with widely involute leaves and longer floral scapes (Fig. 4).

\section{Discussion}

When carrying out the morphological comparison between the different Puerto Blest specimens, we consider the possibility that the Pinguicula with very involute leaves corresponds to Pinguicula antarctica.

P. antarctica and P. australandina are species that can appear to be very similar. Faced with different environmental conditions, the leaves can be more or less involute and their colors can vary from yellowish green to reddish (personal observations). These differences even occur in the same species 

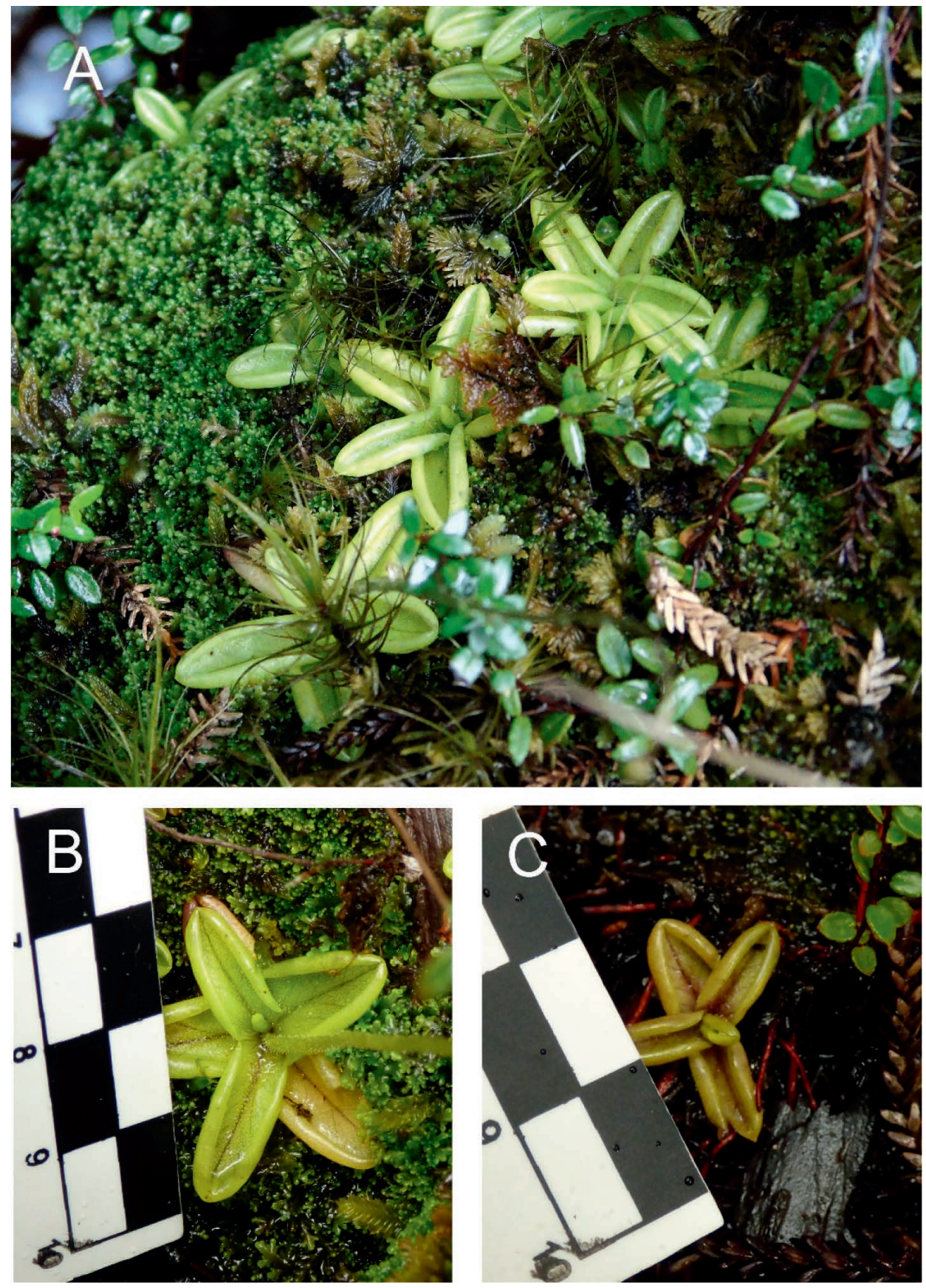

Figure 4: Several specimens of the Pinguicula with very involute leaves in Puerto Blest. (A) Group growing on moss and logs. (B) Adult specimen with developed floral scape. (C) Smallest specimen. Photos taken on 01/07/2020 


\begin{tabular}{|c|c|c|c|}
\hline $\begin{array}{l}\text { Comparison } \\
\text { reference }\end{array}$ & Organ & P. australandina & P. antarctica \\
\hline$\# 1$ & Length of floral scape & $2-5 \mathrm{~cm}$ long. & 4.5-20 cm long. \\
\hline$\# 2$ & Spur & $\begin{array}{l}2-3 \mathrm{~mm} \text { conical and with } \\
\text { pointed end. Solid green } \\
\text { or yellow. }\end{array}$ & $\begin{array}{l}1-1.5 \mathrm{~mm} \text {. shaped like a } \\
\text { sack. With parallel violet } \\
\text { lines. }\end{array}$ \\
\hline$\# 3$ & Corolla's shape & $\begin{array}{l}\text { Sub-isolobada. The } 2 \\
\text { petals of the upper lip are } \\
\text { sub-equal to the } 3 \text { of the } \\
\text { lower lip. }\end{array}$ & $\begin{array}{l}\text { Bilaviated. The } 2 \text { petals } \\
\text { on the upper lip are } \\
\text { considerably shorter than } \\
\text { the } 3 \text { on the lower lip, } \\
\text { almost half. }\end{array}$ \\
\hline$\# 4$ & $\begin{array}{l}\text { Presence of glands in } \\
\text { floral scape }\end{array}$ & $\begin{array}{l}\text { The entire scape } \\
\text { moderately covered with } \\
\text { glandular hairs. }\end{array}$ & $\begin{array}{l}\text { Almost glabrous in the } \\
\text { upper part of the stem, } \\
\text { the presence of glandular } \\
\text { hairs increases towards } \\
\text { the base. }\end{array}$ \\
\hline$\# 5$ & Corolla's color & $\begin{array}{l}\text { Pink, white*, lilac or } \\
\text { purple }\end{array}$ & White \\
\hline$\# 6$ & Palate's location & $\begin{array}{l}\text { Below the middle lobe } \\
\text { inside the tube }\end{array}$ & $\begin{array}{l}\text { At the base of the middle } \\
\text { lobe of the lower lip. }\end{array}$ \\
\hline$\# 7$ & Fruit shape $e^{* *}$ & Globular or ovoid. & $\begin{array}{l}\text { Elongated, slightly } \\
\text { cylindrical, with a flat } \\
\text { edge }\end{array}$ \\
\hline
\end{tabular}

under different environmental conditions (Aranoa 2018) which could lead to confusion. However, the differences that ensure the determination for these species are found in the floral organs.

In addition to the morphological differences compared in Table 2, photos provided by the Puerto Blest tourist guides were reviewed to complement this comparative analysis. In this photographic review, a flower of $P$. antarctica is found in good condition in that locality (Fig. 5), thus confirming the presence of both species in the same location.

In consultation with other specialists of the genus Pinguicula from Latin America (Fernando Rivadavia and Oliver Gluch), the question was raised about another record of overlap between these two Pinguicula species. In Rodriguez et al. (2008) both species were recorded, but P. australandina in the Baker River Basin and P. antarctica in the Pascua River Basin, in Chile. Both basins have marked differences in location (Sandoval et al. 2016), not being a registered case of habitat overlap.

\section{Conclusion}

In January 2020, P. antarctica was found in the Puerto Blest bog. This is the most northern record for this species in Argentina, expanding its known distribution to Tierra del Fuego and Isla de los Estados, Santa Cruz, Chubut, and Río Negro. At the same time, in the present study, P. antarctica and $P$. australandina were found in an area of less than $400 \mathrm{~m}^{2}$ in the Puerto Blest bog (Fig. 6), being the first record of an overlap between $P$. antarctica and $P$. australandina. 
Table 2. Visual comparison between the floral characters of the Pinguiculas. All photos correspond to the Puerto Blest peat bog, except for \#2 Spur and \#4 Presence of glands in floral scape on $P$. australandina (\# refers to Table 1).

\begin{tabular}{|c|c|c|c|}
\hline $\begin{array}{l}\text { Comparison } \\
\text { reference }\end{array}$ & P.antarctica & P.australandina & Discussion \\
\hline $\begin{array}{l}\text { \#1 Length of } \\
\text { floral scape }\end{array}$ & & $\begin{array}{l}0 \\
<a<<\end{array}$ & $\begin{array}{l}\text { P.australandina } \\
\text { exhibits a scape } \\
\text { between } 2-5 \mathrm{~cm} \text { long } \\
\text { (8). P.antarctica's } \\
\text { can greatly exceed } \\
\text { this length, as } \\
\text { evidenced by } \\
\text { photographs and } \\
\text { herbal material. } \\
\text { On-site photos taken } \\
\text { in Puerto Blest on } \\
01 / 07 / 2020 \text {. }\end{array}$ \\
\hline \#2 Spur & & & $\begin{array}{l}\text { The inflorescences } \\
\text { found were in an } \\
\text { advanced flowering } \\
\text { stage. The spur's } \\
\text { sack-shape is clear in } \\
\text { P.antarctica, even } \\
\text { when comparing with } \\
\text { an old corolla of } \\
P \text {.australandina } \\
\text { which keeps its sharp } \\
\text { conical shape. }\end{array}$ \\
\hline $\begin{array}{l}\text { \#4 Presence } \\
\text { of glands in } \\
\text { floral scape }\end{array}$ & & & $\begin{array}{l}\text { P.australandina is } \\
\text { moderately covered } \\
\text { with glandular hairs in } \\
\text { the top of scape, but } \\
P \text {.antarctica is almost } \\
\text { glabrous. }\end{array}$ \\
\hline \#7 Fruit shape & & & $\begin{array}{l}\text { The fruits of the two } \\
\text { species are slightly } \\
\text { different }\end{array}$ \\
\hline
\end{tabular}




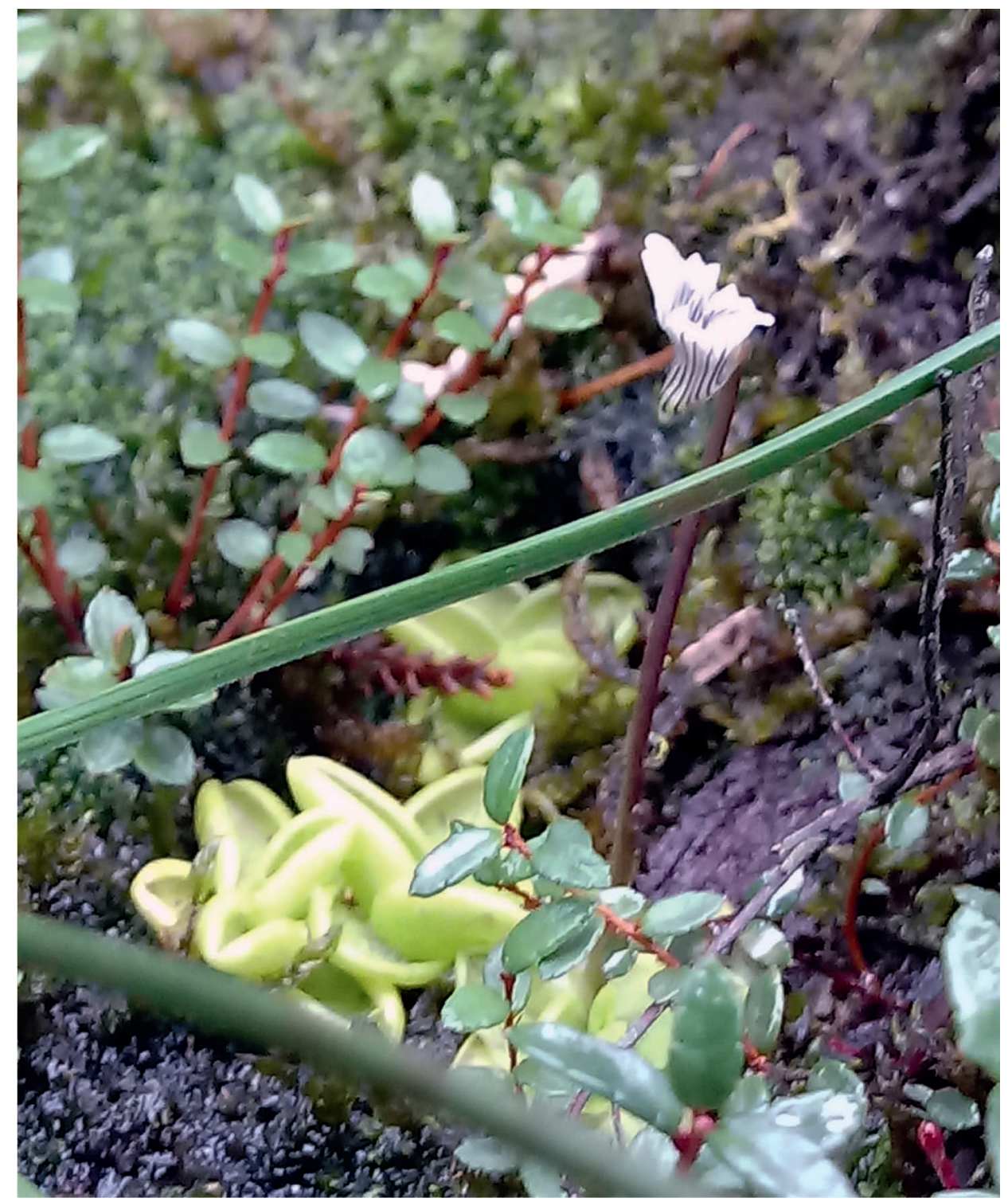

Figure 5: Pinguicula antarctica in flower in the bog of Puerto Blest. Maria Fernanda Tazzin.

Acknowledgements: To Fernanda Tazzin and her lovely family, for helping us so much. Without their support, this research would not have been possible.

To Nadia Valeria Velázquez Barloa, for the time she spent helping us with the presentation of the research project.

To Cecilia Núñez, from the North Patagonia Regional Office, and Susana Seijas, from the Nahuel Huapi National Park, for trusting us and having stimulated the investigation.

To Danel Josu Aranoa, Belén Arce, Ignacio, and Juan Merino Mancioli, for having collaborated with the locations to understand more about the Pinguiculas of the Nahuel Huapi NP. 


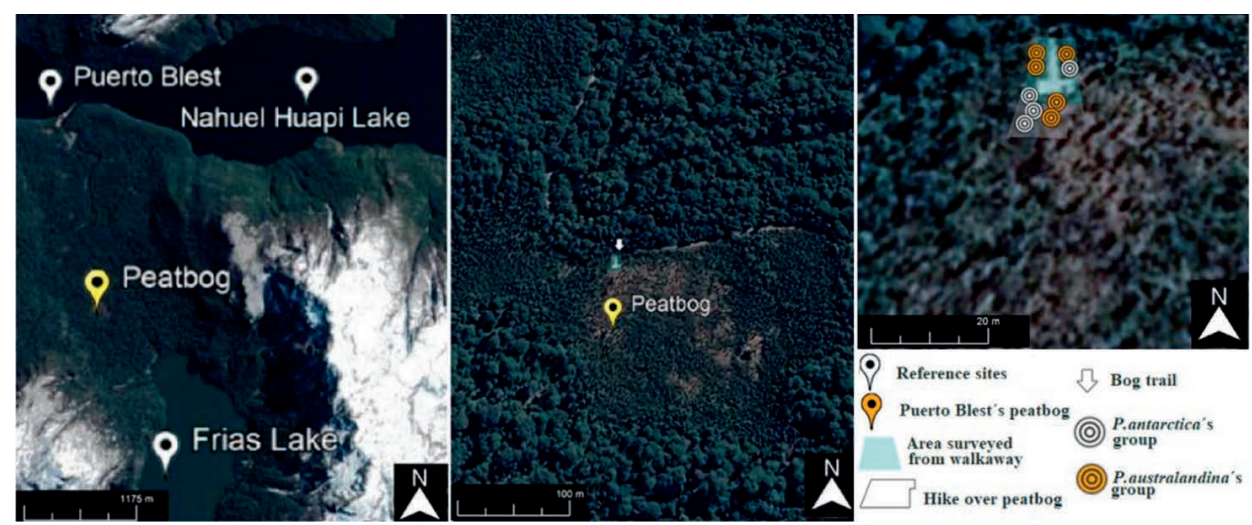

Figure 6: Spatial distribution of $P$. antarctica and $P$. australandina found in the study area.

To Patricio Gregoris, for his photo of $P$. antarctica and all the information shared about the native carnivorous flora of Patagonia.

To Sandra Mantoani, for her insistent actions over time to make dreams come true.

To Mariano Rubén Saviello, for encouraging the spirit of the publication.

To Fernando Rivadavia and Oliver Gluch, for their contributions to this publication.

To Manuel Zurbano, for the English translation of this research.

\section{References}

Aranoa, D.J. 2018. In search of Andean Pinguicula. Carnivorous Plant Newsletter 47(3): 101-104.

Brion, C., Puntieri, J., and Grigera, D. 1988. Flora de Puerto Blest y sus alrededores. Universidad Nacional del Comahue. Centro Regional Universitario Bariloche. Río Negro. Argentina.

Dawson, G. 1973. Flora Argentina. Lentibulariaceae. Rev. Mus. La Plata, Secc. Bot. 13: 1-59.

Gluch, O. 2017a. Pinguicula nahuelbutensis Gluch (2017). Oliver Gluchs Welt der Fleischfressenden Pflanzen. http://www.gluch.info/pingu67.html.

Gluch, O. 2017b. Revision of Pinguicula (Lentibulariaceae) in Chile and Argentina. Carnivorous Plant Newsletter 46(4): 121-131.

Lampard, S., Gluch, O., Robinson, A., Fleischmann, A., Temple, P., McPherson, S., Roccia, A., Partrat, E., and Legendre, L. 2016. Pinguicula of Latin America. Volume 2. Redfern Natural History Productions. Poole, Dorset, England.

Rodriguez, R., Marticorena, A., and Teneb, E. 2008. Plantas vasculares de los ríos Baker y Pascua, Región de Aisen, Chile. Gayana. Botánica, 65(1): 39-70. https://dx.doi.org/10.4067/S071766432008000100006

Roccia, A. 2018. Additional taxonomic features of Pinguicula chilensis. Carnivorous Plant Newsletter 47(2): 44-46.

Sandoval, V., Ramírez, C., San Martín, C., Vidal, O., Álvarez, M., Marticorena, A., and Pérez, Y. 2016. Diversidad vegetal en las cuencas de los ríos Baker y Pascua (Aisén, Patagonia Chilena). Bosque (Valdivia) 37(2): 243-253. https://dx.doi.org/10.4067/S0717-92002016000200003 